\title{
Artificial lung gas exchanges depend on ECMO settings
}

\author{
F Mojoli, S Bianzina, I Bianchi, G Tavazzi, S Mongodi, M Pozzi, A Orlando, A Braschi \\ From ESICM LIVES 2015 \\ Berlin, Germany. 3-7 October 2015
}

\section{Introduction}

Artificial membrane lung (AL) gas exchanges are usually evaluated according to $\mathrm{PaO}_{2} / \mathrm{FiO}_{2}$ ratio. In addition, dead space ventilation and shunt fraction can be measured by the same equations used for native lungs [1].

\section{Objectives}

To study the effect of AL settings - gas flow (GF), blood flow (BF) and $\mathrm{FiO}_{2}$ - on $\mathrm{AL} \mathrm{PaO}_{2} / \mathrm{FiO}_{2}$ ratio, dead space and shunt, to suggest how to properly monitor these parameters.

\section{Methods}

We performed three different tests:

a) GF changes (from 1 to $10 \mathrm{~L} / \mathrm{min}$ ) in $8 \mathrm{AL}$ at clinically set $\mathrm{BF}$ and $\mathrm{FiO}_{2}$;

b) $\mathrm{BF}$ changes in $6 \mathrm{AL}$ at constant $\mathrm{FiO}_{2}(1)$ and GF (10 L/min);

c) $\mathrm{FiO}_{2}=1$ vs. clinically set $\mathrm{FiO}_{2}$ in $10 \mathrm{AL}$ at clinically set $\mathrm{BF}$ and GF.

We performed pre- and post-oxygenator blood gas analysis and measured $\mathrm{CO}_{2}$ at $\mathrm{AL}$ exhaust port by sidestream capnography, in order to evaluate $\mathrm{PaO}_{2} / \mathrm{FiO}_{2}$ ratio, dead space and shunt.

\section{Results}

a) At clinically set $\mathrm{BF}(4.0 \pm 0.9 \mathrm{~L} / \mathrm{min})$ and $\mathrm{FiO}_{2}$ (0.87 \pm 0.15$), \mathrm{PaO}_{2} / \mathrm{FiO}_{2}$ ratio did not correlate with GF, whereas dead space progressively increased with $G F(R=$ 0.7904, $\mathrm{p}<0.0001$ ) (Figure 1).

b) Data were collected at basal $(3.3 \pm 0.7 \mathrm{~L} / \mathrm{min})$, increased $(4.1 \pm 0.8 \mathrm{~L} / \mathrm{min})$ and decreased $(2.5 \pm 0.6 \mathrm{~L} / \mathrm{min})$ $\mathrm{BF}$. With the progressive increase of $\mathrm{BF}$, dead space did not change, whereas $\mathrm{PaO}_{2} / \mathrm{FiO}_{2}$ ratio decreased and shunt increased $(\mathrm{p}<0.001)$ (Figure 2).
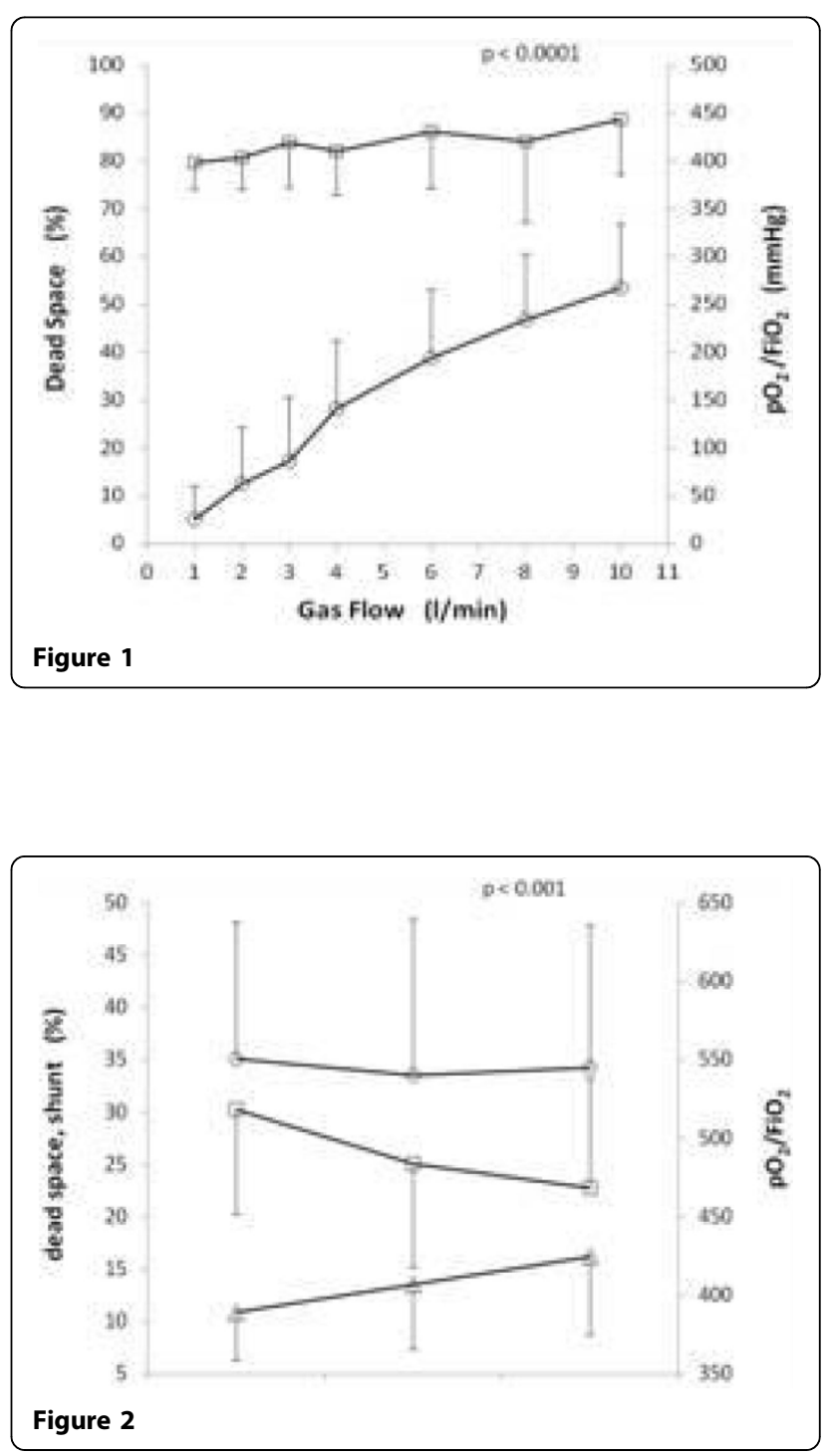
c) At clinically set BF $(3.5 \pm 1.1 \mathrm{~L} / \mathrm{min})$ and GF $(5.1 \pm$ 2.4 $\mathrm{L} / \mathrm{min}$ ), the mean difference \pm standard deviation of $\mathrm{PaO}_{2} / \mathrm{FiO}_{2}$ ratio and shunt obtained at clinically set $(0.80 \pm 0.20)$ vs. $\mathrm{FiO}_{2}=1$ was $-76 \pm 109 \mathrm{mmHg}$ and 2.1

$\pm 11.6 \%$, respectively.

\section{Conclusions}

To properly monitor $\mathrm{AL} \mathrm{CO}_{2}$ removal and oxygen transfer, evaluations should be performed at constant GF and at $\mathrm{FiO}_{2}=1$ and constant $\mathrm{BF}$, respectively.

Published: 1 October 2015

\section{Reference}

1. Castagna L, Zanella A, Scaravilli V, Magni F, Deab SA, Introna M, et al: Effects on membrane lung gas exchange of an intermittent high gas flow recruitment maneuver: preliminary data in veno-venous ECMO patients. J Artif Organs 2015 Mar 26, [Epub ahead of print]. on ECMO settings. Intensive Care Medicine Experimental 2015 3(Suppl 1): A514.

\section{Submit your manuscript to a SpringerOpen ${ }^{\mathcal{O}}$ journal and benefit from:}

- Convenient online submission

- Rigorous peer review

- Immediate publication on acceptance

- Open access: articles freely available online

- High visibility within the field

- Retaining the copyright to your article 